\title{
Centenary of the Salvadoran Red Cross
}

The Salvadoran Red Cross this year celebrated the hundredth anniversary of its foundation. For the occasion the President of the $I C R C$ was in El Salvador from 19 to 25 April; he was received by the highest authorities of the country and, on 24 April, he attended the opening session of the ceremonies which marked the centenary of the National Society of the Salvadoran Red Cross. He conveyed the congratulations and best wishes of the ICRC, the founding body of the Red Cross Movement, to this National Society with which it has been co-operating closely and very actively for many years.

The International Review very cordially associates itself with these congratulations and good wishes.

\section{Address by the ICRC President for the Centenary of the Salvadoran Red Cross}

It is an honour and a source of great satisfaction for me, as President of the International Committee of the Red Cross, to celebrate with you the hundredth anniversary of the Salvadoran Red Cross Society.

On the occasion of this ceremony, the ICRC wishes to convey its sincere congratulations to the President of the Salvadoran Red Cross, to all who work with it, its managing committee, its officers, Grey Ladies, first-aid workers and volunteers, who follow the path set out by their predecessors and perform their humanitarian task with exemplary dedication and selflessness.

In the tragic situation which has now prevailed in your country for several years, the activities carried on without respite by the Salvadoran Red Cross bear witness to the humanitarian ideal which inspired the founders of your National Society a century ago. 
One of the ICRC's tasks, under its mandate, is the recognition of new National Societies and it keeps also a record, in its archives, of the salient events in their history. With your permission, I would like to mention briefly some events in the history of the Salvadoran Red Cross from which a great deal can be learnt.

When the Salvadoran Red Cross Society-the first in Central America-was founded in 1885 , your country had been a party to the first Geneva Convention of 1864 for the Amelioration of the Conditions of the Wounded in Armies in the Field since 30 December 1874. Aware of the serious tensions prevailing at the time in Central America, some influential and respected citizens, engaged in trade or agriculture, had the foresight to think about the consequences of a possible armed conflict and to decide on the urgent measures to be taken in order to ensure fast relief for the victims, if the need arose.

These pioneers, Leon Dreyfuss, Astor Marchesini, Pilar Lagos, Augusto Bouineau and Miguel Yúdice, were immediately granted the support of the Head of State, Dr. Rafael Zaldivar, and especially that of his wife, Doña Sara Guerra de Zaldivar, who took an active part in setting up the new Society. The initial statutes, drawn up by Don Astor Marchesini and Don Luis Van Dyk, were approved by the Government on 13 March 1885 and published in the official gazette the very next day.

War broke out less than three weeks later. Straight away, the Society was put to the test and proved its usefulness. On 2 April 1885 , in the vicinity of the city of Chalchuapa, two Salvadoran Red Cross doctors, Herman Prower and Juan Padilla Matute, showed outstanding dedication, efficiency and courage during the "Batalla de Justo Rufino Barrios".

When peace had been restored, the Salvadoran Red Cross assisted the public health services in caring for the victims of cholera, smallpox and bubonic plague. From the outset, the Government of El Salvador supported the work of the Red Cross and attended the International Red Cross Conference held in Rome in 1892 and the ensuing Conferences held in Washington, Geneva and The Hague.

Some of you may remember the tragedies caused in 1917 and 1918 by earthquakes in San Salvador. On that occasion, and again during subsequent disasters, the Salvadoran Red Cross proved that it was able to give immediate aid and assistance to the victims of natural disasters. 
Better still, aware of the fact that the Red Cross principle of solidarity, based on a truly universal conception of mankind, could not possibly be confined to the ordinary boundaries of the national community, the Salvadoran Red Cross extended its relief activities to neighbouring countries when they had to deal with natural or man-made disasters.

In 1924 it helped the victims of internal disturbances in Honduras and sent to Tegucigalpa a medical team-doctors and nurses with all the necessary material-to care for the sick and wounded of both parties, without discrimination.

On 25 April 1925, shortly after this new proof of solidarity, the ICRC had the pleasure of officially recognizing the Salvadoran Red Cross. It was accredited to the other National Societies and soon was admitted to the League, of which it became a member on 24 June 1925.

Since then, the Salvadoran Red Cross has had ample opportunity to prove its attachment to the humanitarian ideals of its founders and its determination to face the tasks imposed upon it by the difficult times your country has lived through.

Witness the close and efficient co-operation established in 1980 between your Society and the International Committee of the Red Cross to give medical and nutritional assistance to the populations afflicted by the conflict which tears your country apart so tragical$1 y$, and to disseminate knowledge of the essential humanitarian rules among the general public and the armed forces.

This joint action has now become the most extensive assistance and protection operation carried out by our institution in Latin America. Consequently, before coming to the end of this brief review, I wish to pay tribute to the Salvadoran Red Cross leaders, relief workers and volunteers who carry out their sometimes extremely difficult missions in an exemplary and true Red Cross spirit.

We were very deeply distressed by the tragedy of 5 March 1984, when two volunteer workers were killed in an ambulance while bringing relief to wounded in the village of Guadalupe. I wish to take this opportunity to pay tribute to their memory and once again appeal urgently to all combatants to respect the staff and the emblem of the Red Cross, everywhere and at all times.

Dear friends of the Salvadoran Red Cross, as long as your country has men and women prepared-despite all the difficulties and all the dangers - to do their duty and even more than their duty, in a true Red Cross spirit of humanity, neutrality and impar- 
tiality, the Salvadoran Red Cross will be able to face the future with confidence and carry out its humanitarian task successfully.

Over the past thirty years, the world has undergone profound changes. Unfortunately, the number of conflicts has constantly increased on all continents. At the same time, fundamental humanitarian values have been questioned and we are greatly concerned to see that, very often, political interests compete with the most vital interests of victims. We cannot be passive onlookers of this development. We cannot accept that the fundamental principles of the Red Cross and the provisions of international humanitarian law be flouted. The credibility of the Red Cross and its strength rest on its willingness to do everything in its power to prevent despotism and violence against defenceless victims in any country ravaged by conflicts. Now more than ever, the needy, the forsaken, the prisoners, the wounded, look to the Red Cross for protection and assistance.

Your Society, Mr. President, will certainly have to exert further efforts in the century to come, but so rich a past and present are a guarantee for the future and I wish to convey, on behalf of the International Committee, my very best wishes for its future activities in the service of humanity and peace. 